\title{
The Interests of the European Union in Providing Cooperation and Verification Mechanism (CVM) Assistance to Bulgaria in the Midst of Euroscepticism
}

\section{Eska Dwipayana Pulungan}

Department of International Relations, Universitas Gadjah Mada, Daerah Istimewa Yogyakarta, Indonesia eskapulungan@gmail.com

Submitted: 28 February 2019; Revised: 29 December 2019; Accepted: 27 February 2020

\begin{abstract}
Abstrak
Penelitian ini bertujuan untuk menggambarkan peta politik Uni Eropa (UE) dalam memperluas wilayahnya setelah Tembok Berlin runtuh. Sebelumnya, pemberian status keanggotaan dengan bantuan khusus tidak pernah diberikan oleh UE kepada negara manapun. Namun, Bulgaria mendapatkan bantuan khusus keanggotaan yaitu Cooperation And Verification Mechanism (CVM). Pemberian bantuan keanggotaan ini dinilai tidak tepat karena pada saat status tersebut diberikan Euroscepticism sedang berada dalam puncaknya. Negara anggota seperti Inggris, Belanda dan Jerman menilai memberi bantuan khusus kepada anggota agar dapat menyesuaikan ke dalam standar UE akan memperberat kinerja institusi. Dalam kasus ini, The Gains of EU Enlargement dipakai untuk melihat apa yang ingin diperoleh UE dalam memberikan bantuan CVM kepada Bulgaria. Pendekatan ini menjelaskan bahwa UE ingin Bulgaria di Eropanisasi secepatnya untuk mencapai stabilisasi keamanan wilayah Eropa baik secara internal maupun eksternal. Dalam keputusan pemberian bantuan CVM, agenda mencapai kepentingan eksternal paling mendominasi yaitu agar UE dapat mengawasi pengaruh Rusia terhadap Bulgaria. Maka keanggotaan Bulgaria dalam institusi membuat Rusia tidak bisa lagi menggunakan negara bekas sekutunya sebagai alat propaganda untuk mencampuri urusan Eropa, terutama mengenai kebijakan gas impor Rusia menuju Eropa.
\end{abstract}

Kata Kunci: Uni Eropa, Bulgaria, Kriteria Kopenhagen, Cooperation and Verification Mechanism (CVM), euroscepticism.

\begin{abstract}
This research aimed to describe the political map of the European Union (EU) in expanding its territory after the fall of the Berlin Wall. EU never granted membership status with special assistance to any country before. However, Bulgaria had received special membership assistance called the Cooperation and Verification Mechanism (CVM). The granting of this membership status was controversial because it was given when Euroscepticism was on its peak. Member countries such as the United Kingdom, Netherlands, and Germany considered that granting different membership status to fulfill the EU's standards would aggravate the institutional performance. This case employed The Gains Of EU Enlargement to analyze what interests the EU wanted to gain in providing CVM assistance to Bulgaria. This approach explained, the EU wants to accelerate the Europeanization process of Bulgaria to reach the stabilization of European region security both internally and externally. However, external interests dominate the most, in order that EU can control the influence of Russia to Bulgaria. So, Bulgaria's membership makes Russia unable to use its former ally as a propaganda tool to interfere in European affairs, especially regarding Russia's imported gas policy towards Europe.
\end{abstract}

\section{INTRODUCTION}

Based on the Eurobarometer survey, the most significant increase in skepticism about the European Union (EU) occurred in 2007, in coincidence with Bulgaria being accepted as a member of the EU on 1 January 2007. Although Bulgaria has become part of the
EU, many member countries doubt the country's ability to implement the values adopted by the EU (European Commission, 2015). Bulgaria's condition, which is categorized as a developing country in Europe, has even experienced a trade deficit ahead of its membership in 
the EU, causing many EU member states considered that Bulgaria's membership would only likely to absorb the EU funds rather than positively contribute for both the EU and its member states. Skepticism to Bulgaria's membership in the EU is also related to security, migration, and financial issues, which are deemed to potentially destabilize the economy and the politic of the EU's member countries (Evans \& Mellon, 2015).

Economically and politically, countries joining the EU evoke complex problems that must be solved. For example, the EU must expand policies regarding cost-intensive on common agricultural policy and structural funds in new member countries, as well as push for economic reforms to join the economic and monetary union (EMU), free movement of workers in the European Single Market, control of crime rates and environmental compliance standards (Nello, 2007).

From the complexity of these requirements, Bulgaria experienced a problematic membership. Its adaptation process in the political, economic, and legal fields was longer than the other member countries. Therefore, the EU has softened the membership criteria for Bulgaria under the Cooperation and Verification Mechanism (CVM). CVM is a collaboration formed by the European Commission to assess Bulgaria's commitment after joining the $\mathrm{EU}$ in reforming justice, combating corruption, and organizing the crime. CVM has been invoked as the country wants to fulfill the EU norms and regulations contained in the Copenhagen Criteria (Grabbe, 2002).

The criticism of Bulgaria's membership has attracted attention from the UK government. The UK has been wary of Bulgaria's membership since 2004, the year the state was expected to enter the EU but failed because the country could not meet the EU standards including democratic reform and the rule of law (Miroslav \& Damnjanovic, 2014). Several factors affected the process of Bulgaria's Europeanization process on accessions in 2004 and 2007. The main factor was the low maturity of the democratic structure adopted by the state.

Historically, it was affected by the collapse of communism, which had previously been adopted by the state, making it difficult to change the absorption of European values. Poor governance and poor adopted legal norms made it difficult to position itself at the EU level. Therefore, the top priorities for the EU were to carry out socio-economic reforms and democratic transitions through political guidance and empowerment of resources, which were quite different from countries that have joined.

As the most skeptical country in the region, the UK criticism to Bulgaria indicates the distrust of the country to the EU concerning the careless expansion of membership (Workpermit, 2007). One of the consequences, the UK has renewed its membership in the EU through a referendum in 2016, whereby $52 \%$ of the people agreed to leave the EU. The results show that the UK's dissatisfaction toward the EU was related to its several policies on migration and monetary matters (Raitio \& Raulus, 2017). It caused the UK to withdraw its contribution to the EU, especially concerning migration and financial assistance. Therefore, there was an assumption that the bureaucracy in the EU has begun to soften, in which there were democratic deficit and unwillingness to adopt the principles of subsidiarity and proportionality properly, thus eliminating the UK balance of competence in the EU.

Bulgaria's membership in the EU has further led to the growing of anxiety, especially regarding the problem of job seekers. Member countries such as France, the Netherlands, and Belgium required Bulgarians to obtain a work permit before entering their country. While in the UK, employers should apply for a work permit if they wanted to hire Bulgarian migrants. The UK also implemented a rule of not providing claims for work benefits in the first three months of the arrival of Bulgarian migrants in its territory. However, it could be provided if they fulfilled the supporting conditions related to the existence and employment provisions of the immigrants after six months of work (Pop, 2018).

Those restrictions policies have been enforced to Bulgarian immigrants because they have inadequate skills. They were expecting many social benefits from the host governments, begging, and even committing crimes in the destination countries. Moreover, the problems over the progress of reform made by Bulgaria were still under discussion in the EU. It was also the background of major political parties in Germany, such as the Christian Democrat Party and the Christian Social Union, which 
urged the government to prevent social assistance abuse and demand Bulgarian migrants to not get social benefits during the first three months of being in their country. If they abused social support, they should be immediately repatriated and prohibited from returning to Germany (Hewitt, 2014).

The problem regarding Bulgarian migrants then became more urgent to be discussed by the EU member countries, because on 1 January 2014, the EU determined that Bulgarian workers were free to move in the region, because 9 of the 26 member countries had previously restricted the movement of Bulgarian workers, including Austria, Belgium, the UK, France, Germany, Luxembourg, Malta, the Netherlands, and Spain (European Migration Network, 2018).

France, Germany, and the Netherlands' skeptical attitude on the reform of domestic justice and law enforcement in Bulgaria indicated that the induction of Bulgaria into the EU should be supervised, through the CVM, to improve the Bulgarian justice system to be able to deal with corruption and controlling the rates of crimes within the country in order to conform with the EU standards (Chandler, 2017).

\section{LITERATURE REVIEW}

Several studies had discussed the acceptance of new membership in the EU, such as Fawcett and Hurrel (1995), Haas (2004), Scully and Jones (2010). They stated that the $\mathrm{EU}$ is an institution created to accommodate the interests of European countries both economically and politically. In the expansion of the European continent, the unification of countries in the region under the EU legal regulations poses internal dilemmas, such as the increasing skepticism of member states.

Concerning the increasing skepticism in Europe, before Brexit occurred, Baldwin (1995) explained that the public from the enlargement of the CEE member countries is more interested in discussing further expansion while the 15 old member countries tend to withdraw from the issue of territorial expansion. Then in 2017, Wincott's literature explained why one of the old crucial members decided to withdraw. Withdraw occurred because of the disappointment of the public and the UK government towards the EU. It is because the EU restricted the dominance and political influence of the UK in Europe, including its authority in controlling migration from the Eastern European region. UK leaves the UE, meaning that it would have full of control over its borders and migration issues and thus, it reduces the EU authority over the UK, especially the Court of Justice and Commission of the EU. However, the phenomenon of Brexit raised a question about whether all the EU regulations or policies would curb its members and cause similar phenomena such as Brexit due to the increase of distrust of the built integration.

The specialty of Bulgaria acceptance was written by Baç and Cicek (2016) in their research. They found accession negotiations to the EU after the Cold War had prioritized political interests. They compared Bulgaria and Turkey. When the EU sees an urgency political interest in accepting membership of a country, the EU will regulate timing and sequence of the opening of chapters in Acquis, benchmarks, and then playing its role to assuring member countries that the members joined are well deserved. The study further found that EU efforts to accept Bulgaria membership under special assistance were unbelievable. The EU is politically trying to bring Bulgaria closer to Europe, but not with Turkey. Although not a member of the institution, the EU considers Turkey to have a close relationship with Europe. Since 1945, Turkey has declared itself as part of Europe and has signed an Association Agreement with the EU in 1963 and applied for full membership in 1987 but was refused.

It is different from Bulgaria, which became the part of the Warsaw Pact, that was automatically separated from western order until the end of the Cold War. The Cold War dynamics caused the EU to immediately carry out the Europeanization of CEE, including Bulgaria. Bulgaria instantly entered the queue of CEE members as the next potential candidates. In 1997, it became an essential EU evaluation point placing Turkey merely as an applicant but giving Bulgaria a candidate status. In fact, both countries had the same progress in fulfilling the political aspects of the Copenhagen Criteria. In line with the research above, Uysal (2013) also found the dynamics of the Cold War causing the EU to Europeanize former communist countries immediately. The EU has set Bulgaria as a model 
for the Balkan region. If Bulgaria successfully implemented European values, then the same thing is expected to happen in the Balkans.

EU's enlargement to Eastern Europe involves the enthusiasm of Eastern European countries to be a part of Europe. The EU welcomed this enthusiasm. Nevertheless, the EU's old members warn the EU to remain strict in expending its region to CEE countries because every CEE country has a different level of ability to implement EU values. Due to this different level of ability, a democratic deficit has always been associated with Euroscepticism, where the old members of the EU assume that the UE now is too bureaucratic and does not heed their advice, especially regarding its expansion. The UE now only makes rules that must be fulfilled by the next candidate members without considering the political and economic conditions of member countries when the EU expands its membership to developing countries (Bardi et al., 2002). It is undeniable that in expanding the territory to CEE countries, the EU wants to create new power in the international system by making it the main actor. Therefore, it is essential for the EU to make rules to be obeyed by its members without exception (Yesilada et al., 2006).

Ilonszki's research focuses on studying the member countries of Central and Eastern Europe (CEE). Ilonszki (2009) explained that the public's views on European integration were strongly influenced by the political atmosphere of national governments, which shaped people's perceptions about the EU. However, it is biased when compared to Western Europe. Western Europe assumed specific policies emerging at the EU level significantly affected the views of their people, causing Western European countries to take political action to accommodate the right of their people. Hence, although the economic, political, and security performance of Western European countries were good in the EU level, the level of national satisfaction with the EU could decrease along with the emergence of specific policies in the EU level, such as an integrated taxation system, a general social security system, a single foreign policy and more assistance to member countries experiencing social or economic difficulties. This situation illustrated that the most skeptical people came from Western Europe or member countries with stable economic and political conditions. It is called Eurosceptic, which showed there was a dividing line between Western and Eastern Europe in the EU, which could impact the EU's future.

Andreev (2009) explained that after Bulgaria's membership in the EU, it had international obligations, including creating an international community and healthy business development. However, along with its presence in the EU, the Bulgarian community was experiencing disappointment and the rise of protests from the rising prices, the closure of the domestic industry, which was considered ineffective, and the loss of national sovereignty. The Bulgarian government should take such a policy to fulfill its international obligations as a member of the EU and also meet the requirements of the EU. These actions were meant to fulfill its internal improvements based on the terms conditions and deadlines proposed by the EU. Bulgaria took the policy because of its inability to react to external problems, such as negotiations in the reformed treaty of the EU. The reformed treaty of the EU concerned about how to position the state in EU institutions and the state's position in recognizing Kosovo as an independent state.

The previous research did not specifically examine one post-communist country in the EU, namely Bulgaria, which had not undergone reforms as well as previous CEE members, which had successfully implemented European norms. This research also examined the effects caused by the joining of developing and corruption-prone countries, such as Bulgaria, in the EU and how the reaction of other member countries to see such conditions. It often led to arguments against the rejection of integration, even in the expansion of membership in the future. Indeed, it could be seen in the acceptance of membership in 2007, which raised the increasingly complex problems that should be faced by the EU.

\section{THEORETICAL FRAMEWORK}

Looking from the Kantian insight, the $\mathrm{EU}$ is an institution that promotes peace, democracy, stability, prosperity, human rights, and the rule of law. The main idea of the EU is to develop political and economic stability 
so that the expansion of the territory is considered as a necessity to give more benefit to the members by integrating more countries in the region into the institutional framework. Hence, in looking at the status of Bulgaria's membership under the help of CVM, it is essential to see it using the gains of EU enlargement (Schneider, 2009).

The gains of EU enlargement in the economics saw that the EU expansion contributed to economic growth for both old and new member countries. Some of the economic benefits of integration are, first, by eliminating tariffs and trade quotas, the integration would reduce transaction costs. Second, by including new and developing markets in a single market, the integration would increase investment and trade. Third, by changing the legal system and regulation of the domestic market, the integration would have a positive effect on the labor and the capital market. Fourth, by fostering specialization in the production process, the integration would lead to more efficient capital allocation and increase productivity.

Furthermore, regarding the expansion of the EU in the political aspect, the use of gains of EU enlargement would be more profitable when compared to the benefits in economics. The contemporary EU regionalism currently argues that limiting the acceptance of developing countries into institutions is considered to pose a severe threat, that is detrimental to EU political stability (Schneider, 2009). Migration due to poverty, crime, and the risk of conflict and war will be considered for further expansion. These arguments are adequate to explain the economic and political motivations to expand as widely as possible. This argument also helps to explain why European countries bordering with unstable countries tended to choose and support expansion rather than countries that do not border with unstable states.

The EU tried to bring Bulgaria to meet the standards as implemented by the previous member countries. The decision was taken because it was a rational actor that behaved in an actual manner and could be evaluated. Every decision made had a motive that could influence the choices or behavior of other actors so that the existence of institutions became more strategic. It was because every decision taken would affect the action of the enemy, including issuing policies in response to the internal state of the institution.
Schimmelfennig (2003) reinforced that the decision to accept CEE countries such a correct action. The positive impact of accepting CEE members will not necessarily be seen. Therefore, the EU should continue to monitor the progress. The EU, in this case, would act as an external party to influence the behavior of domestic member states in carrying out European values (Schimmelfennig and Sedelmeier, 2002).

Furthermore, the EU will pressure all members to comply with regulations by making specific policies. It is considered to be rational because the EU wants to apply the same standard (Schimmelfennig, 2000). In this rational attitude, acceptance of membership explains two main issues - first, preferences and prospective between member states, and second, the decision to expand institutions and policies set for prospective member countries to adjust to European standards. If the EU chose not to provide CVM assistance to Bulgaria after being accepted as a member, it could lead to disruption of regional political and economic stability. Therefore, the expansion of the EU region to the $\mathrm{CEE}$ is a political process that has many factors that cannot be seen to fulfill economic interests.

\section{RESULT AND ANALYSIS EUROPEANIZATION OF BULGARIA \\ Expansion of the European Union Territory to Bulgaria}

Turning from a communist country into a democracy and liberal economy after the Cold War was a common way implemented by the EU for Eastern European countries to join the institution. The most significant agenda to be achieved by the EU was to place the institution as agenda-setter and gatekeeper to Europeanize the Eastern European countries. The membership of Eastern European countries in the institution is considered to provide long-term benefits in economics and politics, which would influence European social norms in the future (Malova \& Dolny, 2008).

Giving a membership to Bulgaria means that the EU had prepared and been willing to help to reform the country; for example, liberalizing the economic and trade system. The assistance aimed to create a higher dependency on Bulgaria to other European countries to foster peacebuilding, trust, and 
prosperity. Such a liberal economic and trade system would ensure Western European companies to open up business opportunities in countries considered stable and give a chance for Bulgaria to adjust to Western European countries by referring to the standards set by the institution. Hence, the integration of Bulgaria into the EU would be more easily achieved, especially after the fall of the Berlin Wall, which is considered as the most fundamental issue in the history of European regionalism (Baldwin, 1995).

\section{European Union Standardization}

In 1990, Europe experienced a new history with the fall of the Berlin Wall marked by the union of West and East Germany. This euphoria at the same time signaled the loss of control of the Union of Soviet Socialist Republics (USSR) in Europe, followed by the growth of democracy across Eastern and Central European. In changing European interaction after the communists faded and welcomed the arrival of European countries, the European Community (EC) transformed into a European Union (EU), which was adopted in the Treaty on European Union (TEU) under the Maastricht Treaty law in 1992.

The EU created a new membership acceptance scheme under the Copenhagen Criteria regulations in 1993 because the Maastricht Treaty had been agreed upon. The Copenhagen Criteria have three points, including; first, it should be a stable state having democracy guarantee, the rule of law, human rights, and respect and protect minority rights. Second, it has a functioning market economy and the capacity to respond to the EU competition and market power. Third, it can carry out membership obligations effectively, including adhering to the EU political, economic, and monetary objectives (European Commission, 2018).

Copenhagen Criteria were decided as the primary requirement that must be possessed to join the $\mathrm{EU}$ to enable the spreading of democracy, maintaining stability, security, and proportional living standards in Europe. Compliance with Copenhagen Criteria would contribute to the formation of a democratic and peaceful Europe. The application of the criteria is also a scheme to unite the economic, political, and legal heterogeneity among countries wanting to join the EU, and thus, the criteria are general standards that should be fulfilled to join the institution (Rezler, 2011).

\section{Bulgaria's Journey to the European Union}

Joining the EU has been Bulgaria's main goal since 1989, which began with an association agreement. Initially, the EU was only interested in opening negotiations on membership with Czechoslovakia, Hungary, and Poland in 1990. When the USSR collapsed in 1991, the EU determined to bring Bulgaria closer to Europe. From the association agreement process, the EU began designing a liberal trade system and financial assistance to Bulgaria. Bulgaria then began its accession to the $\mathrm{EU}$ on 14 December 1995. Bulgaria's situation towards the accession to the EU was greatly affected by the 10-years Yugoslav War, which had the effect of hampering the development of transportation and trade networks, so as hampered the flow of foreign direct investment (FDI) to Bulgaria. Inconsistent macroeconomic policies, slow political instability, and structural reforms made the process of Bulgaria's transition to the EU more complex (Cuaresma et al., 2005).

On 15 February 2000, Bulgaria began negotiation for membership acceptance with the EU. In this negotiation, it obtained EU legal regulations and norms under the Acquis Communautaire by obtaining 29 negotiation points. Points arising from these negotiations are points of agreement that should be improved by Bulgaria before joining the EU.

\section{Postponement of Membership Acceptance from 2004 to 2007}

Bulgaria was not part of the first's generation expansion membership of the CEE region in 2004 because, based on the EU assessment, the commitment to combat corruption and control crime rates and judicial reforms did not work in accordance with established provisions. Through monitoring reports issued, the EU stated that the number of violations of the law and instability of the state, such as widely practiced contract killings, was still a common problem. There was no further investigation of such crimes and no satisfactory demands issued by the court in a similar case to cause a deterrent effect. The possession of firearms, human trafficking, drug smuggling, money laundering, counterfeiting of goods, and unstable currency exchange rates also caused the delay of membership acceptance (Noutcheva \& Bechev, 2008). 
In the postponement of this membership, the EU played a role of tying hands where the elites made a policy to bind member countries by carrying out massive reforms. Market sanctions could also be imposed by reducing FDI and periodic monitoring of reforms made by Bulgaria. Slow reforms made the EU in 2002 excluded Bulgaria from the list of prospective members to be accepted in 2004, then invited Bulgaria back in May 2004 to resume negotiations towards the EU after the expansion of $10 \mathrm{CEE}$ members in that year was completed. The insistence of long-standing members to delay Bulgaria's membership acceptance is the primary factor causing the postponement (Noutcheva \& Bechev, 2008).

The European Commission did not want to impose sanctions on Bulgaria by inhibiting it for membership in the EU, but as Western Europe's public anxiety raised over the EU's expansion, it had decided to press for accelerating the achievement of reform toward Bulgaria. In emphasizing the reform acceleration, Bulgaria should immediately address the most pressing issues such as corruption, organized crime, and improvement of the justice system. The EU was ready to establish a monitoring system or special assistance to monitor the situation of Bulgaria for the first two or three years of its membership if accepted as a member of the EU. Supervision in the form of special assistance had never been conducted for other member countries. Thus, there was an assumption that the acceptance of unstable membership, such as Bulgaria, would form first and second class divisions in Europe (BBC, 2006).

\section{Bulgarian Conditions toward the Establishment of European Union Membership}

In 2006, the European Commission issued a final report ahead of Bulgaria's membership, which would be accepted on 1 January 2007. Broadly, the EU assessed three main components, including politics, economics, and the fulfillment of the Acquis on Bulgarian reform. Fulfilling the political criteria required a follow-up primarily in handling human trafficking. Bulgaria was still a place of transit and origin for human trafficking. The trade of newborn babies, which involving mothers giving birth abroad, could not be handled at all (Commission of the European Communities, 2006).
The absence of mechanisms and legal regulations addressing this problem indicated the lack of Bulgarian efforts in overcoming the problem. Besides, Bulgaria had not yet signed the European council convention on the war against human trafficking. Second, the poor condition of correctional facilities and treatment of inhumane prisoners. Third, child protection, especially for children with disabilities and home facilities for abandoned children. Fourth, protection for people with disabilities and care for people with mental disorders, including the provision of special facilities. Fifth, protection and integration of minorities. Roma minority gypsies were made second-class citizens in Bulgaria. The government needed to provide shelter, education, training, and jobs for them who were jobless to minimize suspicion and crime in society.

In fulfilling the economic criteria, Bulgaria still needed to take and carry out actions, including, first, stabilizing macroeconomic policies and the current account deficit. Second, industrial privatization and restructuring, in this case, the liberalization of the state electricity company, maritime, and gas companies were still needed from the government. Third, improving the business environment. The development of the business world needed facilitation from the slimmer regulations. In this case, it was firmly related to the improvement of the administration and justice system because the regulations issued were considered too long and tended to damage the development of the business world. Fourth, labor market flexibility, improvement of working hours, and bonuses for workers needed to be reviewed so that workers got their rights. Seniority in the workplace also needed to be removed, and improvements in the education system also needed to be reformed to create the character and competitiveness of individuals in the face of the competitive pressures of the world of work in the EU. Regarding the Acquis Communautaire, 13 of the 29 points received by Bulgaria could not be fulfilled.

\section{Providing Cooperation and Verification Mechanism (CVM) Assistance}

When Bulgaria officially joined the EU on 1 January 2007, the European Commission noted that the justice reform was still worst. The reform in the judiciary was focused on the mission of eradicating corruption and 
handling organized crime undermining European norms. If CVM was not enforced in Bulgaria, security measures and prevention against corruption, organized crime, and the improvement of the justice system would not be carried out by Bulgaria. For this reason, the European Commission established the CVM as a transitional step to help Bulgaria overcome the problems (Commission of the European Communities, 2007). According to Taseva (2012), CVM was given to Bulgaria as a guarantee that Bulgaria would continue to reform based on the EU demands both politically and economically, as stated in the Acquis Communautaire. If CVM was not implemented, it would take a long time for Bulgaria to be able to join the EU based on Copenhagen Criteria.

In the same matter, Dimitrova and Buzogany (2004) state that CVM was enforced because Bulgaria was in an unstable condition and far below the standard in implementing the EU fundamental principles and values. It was explicitly designed to overcome the lack of political criteria through improvements to state institutions to ensure the rule of law was truly upheld. It was also designed as a tool to equalize among member countries through the development of dignity, interests, and life quality for all EU citizens if they had joined the institution (Tenzer, 2018).

\section{Bulgarian Reform Achievement under the Assistance of CVM}

There are six benchmarks to see the measurement progress in the implementation of CVM. Significant progress made by Bulgaria was only approved in 2018. First, in judicial independence, Bulgaria had adopted a professional way of working. Transparency and elimination of nepotism in the appointment of positions in the judiciary was a significant step that had been taken in reforming the justice system. Thus, investigating large cases was considered to be more integrated with other institutions without any indication of government intervention. Upon this achievement, the commission decided the first point in the CVM concerning judicial independence was closed regarding the assessment that the steps taken had resembled EU standards (Commission of the European Communities, 2018).

Second, in the legal framework, Bulgaria had adopted the criminal procedure code and criminal code. Taking this step changed the procedure for handling cases in court, especially concerning corruption and criminal cases. The court process was more efficient, and the government had adequate legal references to prevent the legal mafia from utilizing the loopholes of bureaucratic weaknesses in the courts, which so far have been in effect to protect themselves from legal charges. For this achievement, the commission considered that the second point in the CVM did not need to be monitored anymore. Bulgaria was only advised to continue maintaining commitment and improvement to strengthen legal legislation so that the legal mafia was not trying to find an internal network of government.

Third, concerning judicial reform. Fourth, high-level corruption, and fifth concerning corruption in general, including local level and borders. The commission waited for concrete steps to carry out total reforms at this point. It stressed that Bulgaria should follow the recommendations based on the recommendations issued in 2017. There was no closing judgment in points three, four, and five. While in point six, regarding organized crime, Bulgaria had implemented a mechanism for reporting open data to the public regarding the investigated high-level crimes. Bulgaria had also amended the legislation related to the seizure of high amounts of criminal assets indicated to be detrimental to the country. In dealing with high-level crime cases, the commission considered Bulgaria to be so independent and efficient that it decided to close the sixth point.

Through these details, the commission appreciated Bulgaria's performance in carrying out reforms so that the first, second, and sixth points in CVM were closed and considered to have fulfilled the EU standards. This achievement also indicated that the benefits of Bulgaria's membership in the EU would be increasingly obtained. In the following year, CVM remained in force, but the assessment only focused on the third, fourth, and fifth points.

European Commission's recommendation to those points above are, on the third point, about judicial reform. Bulgaria should publish an online reporting mechanism that can be accessed by the public to see the progress which has been successfully made by the judiciary, including listing the strategic steps that will be applied, such as balancing the workload based on the new workload 
standards to prevent case buildup. Fourth, high level of corruption handling. Bulgaria should adopt a new legal framework and apply it well. Adoption and implementation of new laws on public administration aim to strengthen internal oversight in public administration, make a roadmap between related institutions to overcome deficiencies in the investigation and prosecution of cases, and report the results to the public. Fifth, corruption in general, including the local level and borders. The Commission recommends that corruption eradication agencies work together with the Ministry of Home Affairs to eliminate political interests in the regency area which becomes the source of corruption.

\section{THE INTERESTS OF THE EUROPEAN UNION IN BULGARIA}

\section{Achieving Internal Stabilization of Security: Preventing Denial of Expansion of European Union Regions in the Future}

Since the European Commission decided the suspension of Bulgarian membership, which was initially planned to be accepted in 2004 in the fifth expansion, there had been various responses from the existing member states over the EU's attitude, which was accused of forcing an expansion of Bulgaria. The existing member countries considered that Bulgaria's condition was unstable and could damage the dynamics of EU integration. France considered that the addition of a member state with a low per capita income, such as Bulgaria, would burden the EU economy going forward. France was also worried that the acceptance of such member countries would increase the disruption of power among the existing member states in making decisions at the EU level. This fear was reflected when France gave a veto and rejected the ratification of the European Constitution in 2005, and the Dutch later did the same (Jeffery, 2005).

The rejection of the European Constitution resulted from an agreement to continue expanding. The EU was initially dominated by 15 old member countries and followed by the entry of $10 \mathrm{CEE}$ member countries from the Eastern European region. The failure of the ratification of the European Constitution caused the old member states to forbid the EU to expand its membership in the future. This concern arose because the old member countries did not want to accept a surge in migration from new member countries as well as the European economy, which tended to weaken in which the appearance of new members was considered to only aggravate the performance of institutions (Bilefsky, 2007).

Regarding migration, the UK and Ireland were among the 15 old member countries stating that their countries received a disproportionate migration from the expansion in 2004, for which they felt the need to hold even tighter controls to accept migration from Bulgaria. Spain and Italy also experienced an increase in unemployment, hence, it was necessary to limit migration from Bulgaria (Batsaikhan et al., 2018).

This rejection of migration was a fundamental affirmation that Europe's future would be even more unpredictable if the EU continued to expand its membership (Favell, 2008). Such skepticism signifies a sense of exclusivity of the state from integration arising from a high sense of nationalism so that other nationalisms become the inferior, subsidiary, and servile (Harmsen \& Spiering, 2004). The background of Bulgaria, as a post-communist country and membership status under the assistance of the CVM, will threaten the EU integration.

According to Balch and Balabanova, Bulgaria's migration is often associated with organized crime, chaos, disease, and terrorism. Media coverage most influenced public opinion in fostering anti-migration attitudes (Balch \& Balabanova, 2014). Such behavior also adds skepticism to the future of Europe. The behavior of immigrant restrictions, according to Hjerm, arises due to the existence of social strata or classical divisions affecting mainland Europe (Hjerm, 2003).

There are two attitudes in viewing skepticism in the EU today. First, soft Euroscepticism that refers to conditions where there is no objection to the principle of membership, but there is concern or criticism expressed relating to EU policy. It also states that the country's national interest is against the EU policy. Second, hard Euroscepticism refers to a group or opposition that opposes the EU and European integration. It is conveyed in the form of direct advocacy, namely withdrawal from the EU or opposing the existence of countries wishing to join the EU. This opposition is demonstrated through 
the policy-making of countries differing from the EU to oppose deeper integration.

The skeptical form of Western European member countries is classified in hard Euroscepticism in seeing the existence of Bulgaria. The most dominating skepticism is the ongoing integration campaigned by the $\mathrm{EU}$ as well as concern about opportunities for deeper integration in the future. The development of skepticism is formed by public opinion and discoursed by the media and political parties leading to becoming a national discourse against the state involved in integration. Political parties take advantage of the growing skepticism, especially in the run-up to the general election, to attract voters who feel threatened due to their integration into the EU agreement.

Skepticism will continue along with the emergence of anti-European party groups before the election. In addition, it is caused by the old member countries having the option to impose restrictions on the free movement of individuals from Bulgaria for seven years since the establishment of Bulgaria's membership. In seeing this skepticism phenomenon, the EU had strong reasons for accepting Bulgaria's membership by imposing a CVM policy.

Internally, about Bulgaria's membership, the EU provided problem-solving options in promoting and protecting the interests of its member countries in accordance with its conception as a regional institution. Along with the emergence of counter expansion groups, the EU would review the accession agreement with the candidate country before granting the membership status. Therefore, it can be seen that Bulgaria's membership under the status of CVM prioritized the calculation of political benefits rather than economic benefits. It is in accordance with the pattern in The Gains of EU Enlargement proposed by Schneider that the economic benefits will not be the primary aim of the existence of Eastern European countries in the EU but rather the benefits of long-term political gains.

According to Grabbe, the problem that most affected the old member countries concerning the EU expansion was the funding of the EU and the influence of new member states to institution's function, especially if those that joined were developing countries. Different political agendas between old and new members also dominated the discourse to prevent EU expansion. Old member countries would add their priorities to the EU so that it would change and shape the direction of EU politics. However, it would be different from the new member countries, which focused more on improving reforms in their countries, which then were considered to aggravate EU performance.

Internally, member states issued responses related to their respective national interests, which annulled skepticism about their future in the EU. Externally, the EU's actions in implementing CVM amid the accusations of member states that it issued a policy that annulled Bulgaria's shortcomings in fulfilling EU norms and regulations had a policy goal that benefited Europe by realizing equality between countries in Europe by uniting European countries under EU regulation to obtain mutual agreement in responding to foreign intervention. On this basis, the EU continued to expand, and Croatia was accepted as the 28th member in 2013 (Horvat \& Štiks, 2013).

Several countries want to join the EU, according to Scully and Jones (2010), because of the desire to achieve prosperity with the old member states identified as Western European countries. In their argument, even though the European region has fulfilled the standards to join the EU, it is still a group that has extraordinary diversity. In this way, attracting Bulgaria to join EU regionalism under the auspices of CVM is a way to eliminate the gap between Western and Eastern Europe immediately.

\section{Achieving External Security Stabilization: Eliminating Russian Influence}

At present, security should be broadly defined not only limited to the context of the military but also economic and political instability, undemocratic governance, unemployment, and crime are also threats to peace. After the fall of the Berlin Wall and the USSR broke up in the 1990s, 'Return to Europe' became the slogan of the EU in embracing communist-leaning European countries to get closer to the West (Vetličič \& Trtnik, 1999).

In the Gains of EU Enlargement, consideration after the dissolution of the USSR in acceptance of Bulgaria's membership would provide an absolute political advantage 
to the institution. Schneider (2009) argues that ignoring unstable countries in the region can pose a severe threat to the EU's political stability. Migration due to poverty, crime, the risk of conflict, and war will become the primary considerations in seeing the existence of Bulgaria.

In looking at expanding to Eastern Europe, it is necessary to look at the background of member countries before joining the EU. Bulgaria was a communist-leaning country that had close relations with Russia. On the other hand, member countries from the Western European region did not have good relations with Russia (Todorov, 2007). Historically, Bulgaria had a close relationship with Russia before the communist era ended (Brown, 1986). The closeness of Bulgaria and Russia under communist rule brought its influence in the Balkan region. During the communist era, Bulgaria was a loyal USSR satellite in Europe, defeating Hungary, Poland, Czechoslovakia, and Romania. Bulgaria made Russia a representation of the Balkan countries, and Bulgaria also had a strong economic and political dependence on the USSR, especially since the Second World War ended.

The unfortunate economic situation ahead of Bulgaria's membership in the $\mathrm{EU}$ demanded the implementation of CVM. Otherwise, it would take too long to join. Bulgaria was also used as a representation of USSR politics in the Balkans, especially when Romania began to head west. The small achievement of reforms carried out by Bulgaria in fulfilling political criteria and points in the Acquis Communautaire indicated that Bulgaria's political situation was still far from EU standards. Nevertheless, the momentum of its acceptance should be done as soon as possible. The slow pace of reform achieved by Bulgaria is considered to disturb EU externalities, especially in dealing with Russia if the membership acceptance is postponed (Todorov, 2007).

Bulgaria possessed nuclear when the communist era came to power. Bulgaria's nuclear ownership was under USSR rules. In the development of nuclear expansion, Bulgaria had imported gas below the average market price to assist the construction of nuclear installations under the direction of the USSR government. The first nuclear reactor was built in 1974, the second was constructed in 1975, the third reactor was made in 1982, the fourth was created in 1982, and the fifth was built in 1989. They were all located in Kozloduy. In 1966 and 1982, Bulgaria built a Nuclear Power Plant. Hence, it had six nuclear reactors in total.

In 1989, when communism began to collapse, Bulgaria approached Europe under the rules of EU regionalism. In the agreement with the EU, it requested Bulgaria to close its nuclear reactors. The closure of the nuclear reactors was only realized in 1999 when an agreement on EU membership was signed. The closure of the first and second reactors was carried out in 2003, and the closure of the third and fourth reactors was done in 2006 (Tchalakov \& Hristov, 2018).

The EU merely allowed the opening of two of Bulgaria's nuclear reactors. The closure of the previous four reactors occurred because Bulgaria was considered not a country that could be responsible for the safety of nuclear operations. EU member states were only permitted to operate nuclear for the security of electricity supply with strict requirements. In the Energy Union Strategy and European Energy Security Strategy, it is explained that member states need to apply high-level safety standards, security, waste management and non-proliferation, and diversification of nuclear fuel supplies.

At present, the problem arising between the EU and Russia is concerning energy. Energy problems often lead to confrontations between them, especially if it concerns the territory of the former Russian ally. Although Bulgaria has joined the EU, the energy cooperation relationship between Bulgaria and Russia has not changed. Furthermore, Bulgaria became the ambassador for Russia to enter the EU market. Energy issues between Bulgaria, Russia, and the EU are closely related to Bulgaria's nuclear ownership. Bulgaria's nuclear development is on the EU security agenda in accelerating the acceptance of Bulgaria's membership under the CVM in order to gain access to the issue of energy and nuclear control. Before joining the EU, there were fears that Bulgaria's nuclear would continue to be monitored by Russia as well as Russia's means to continue to exert influence in Bulgaria. 
In 2018, Bulgaria planned to develop one of the two remaining nuclear reactors to be reopened and used as a nuclear power plant, as well as provide enormous opportunities for Russia to invest in the project. To support the development plan, the Bulgarian government specifically asked the European Parliament to lift the ban on developing nuclear projects. In 2012, Bulgaria wanted to reopen the renewal of the Belene nuclear installation but ended with the cancellation of the project, which caused the country to pay a fine of $\$ 729$ million to a Russian nuclear company named Rosatom as the largest investor in this project. The cancellation occurred due to the failure of Bulgaria to look for further foreign investors due to the emergence of pressure from the EU and the United States to limit Bulgaria's energy dependence and cooperation with Russia and urge member countries to pay attention to the regulation of energy cooperation with Russia so as not to violate EU energy market liberalization rules (Balmforth, 2018).

In response to the desire of Bulgaria to re-develop its nuclear power plant, the EU stressed that Bulgaria should focus more on achieving public reform, especially in increasing economic competitiveness so that it could be more integrated with the EU. On the other hand, Russian President Vladamir Putin, in the presence of Bulgarian Prime Minister Boyko Borisov at a meeting in Moscow, stated that Russia was very interested in expanding economic cooperation with Bulgaria. Its desire to build deeper economic cooperation with Bulgaria referred to trade data, which increased by $24 \%$ in 2017 and increased investment in the Bulgarian black sea in 2017. President Putin also conveyed historically that in the past, Bulgaria was aided by the USSR in facing colonialism Turkish Ottomans, which should remain the glue of cultural relations between Sofia and Moscow, and thus it should be maintained (Fiorentino, 2018).

Energy security was increasingly important to be implemented in Bulgaria when an infrastructure development project for natural gas transportation emerged in South-Eastern Europe or called as the South Stream Pipeline in 2006. This project changed the composition of the natural gas supply of Bulgaria, which made the rule for Bulgaria to adopt a more active policy as a country of transit. In the development of South Stream, Russia sought the support of former communist countries and also other EU member states such as Austria, Bulgaria, Italy, Serbia, Croatia, Slovenia, and Hungary. To simplify this project, countries joined in the South Stream project tried to debate the EU over the gas cooperation program with Russia. However, the EU stated that the South Stream project was illegal and was against the liberalization of the EU gas market, namely the Rules of the EU's Liberalized Gas Market, but the South Stream member countries wanted to be free from the rule.

In 2013, the European Commission formally stated that the South Stream project had to be completely stopped after the new construction process began in Bulgaria because it violated the EU Competition Rules. Pressure released by the EU had made countries joining the South Stream project to withdraw their support. In response to the EU's decision, Italy stated that it did not support South Stream because the gas pipeline construction project was excluded from the country's priorities. Austria drew total support, and Bulgaria changed its energy policy after the coming pressure from Brussels and Washington (The Economist, 2014).

The EU tended to take on another role for Bulgaria, namely as a representation of the Balkan states. Bulgaria also had historical links with Russia, and Russia had always tried to approach the post-communist countries through the pursuit of bilateral cooperation. Slowly under the CVM, Bulgarian followed the rules and norms of EU law. In this case, Bulgaria's membership, even though it was classified as premature membership, could be a guarantee of territorial integrity in the dynamics of contemporary regionalism. Despite the pros and cons in expanding territories, the EU still firmly declared promising membership to Croatia and the Former Yugoslav Republic of Macedonia, following the acceptance of Bulgarian membership (European commission, 2018). 


\section{CONCLUSION}

Granting the CVM to Bulgaria was an exceptional reference for the EU to see the policy effects of the accelerating membership acceptance even though that country had not been able to follow EU standards. This policy was taken to save the EU political interests in the Eastern European region. Hence, it is not surprising if there are movements appear to anticipate membership expansion because the countries that will join later were Western Balkan countries such as Albania, Montenegro, Serbia, the former Yugoslav Republic of Macedonia, Bosnia, Herzegovina, and Kosovo which are considered unstable and requires a lot of EU funds to reforming each other's internal circumstances.

Author argues, the economic presence of member countries from the Western European region is already stable to bear the costs of operating the Eastern European countries. If they were not Europeanized, they would bring disadvantage in European regionalism. Regarding the fact in globalization era, war with military power will not be occur and not the only one fear and threat anymore, but migration due to domestic political instability, uncertainty in employment, and internal insecurity will be a threat and a nightmare to developed countries which served as the primary goal of individuals from developing countries who feel threatened if they do not migrate immediately. Furthermore, the EU should predict the future of Europe, if neglect these countries, Russia will take action to drive these countries to disrupt the stability of European security. Does not rule out the possibility, cold power patterns can re-emerge because Russia surely not allow its ex-allies to develop on their own without considering its economic and political interests want to achieve in the Europe region. A certain thing the EU also definitely doesn't want.

\section{REFERENCE}

Andreev, S. A. (2009). The unbearable lightness of membership: Bulgaria and Romania after the 2007 EU accession. Communist and Post-Communist Studies, 42, 375-393. doi:10.1016/j.postcomstud.2009.07.001

Baç, M. M., \& Cicek., A. E. (2017). A comparison of the European Union's accessions negotiations with Bulgaria and Turkey: the role of bilateral issues. Journal of Contemporary European Studies, 25(2), 180-196. doi:10.1080/14782804.2016.1198690

Balch, A., \& Balabanova, E. (2014). Ethics, politics and migration: ethics, politics and migration: movement of Romanians and Bulgarians in the UK 2006-2013. Political Studies Association, 36(1), 19-35. doi:10.1111/1467-9256.12082

Baldwin, R. E. (1995). The Eastern enlargement of the European Union. European Economic Review, 39, 474-481. doi:10.1016/0014-2921(94)00053-3

Balmforth, T. (2018, May 21). Bulgaria open to Russian role in nuclear power project. Reuters. Retrieved from https://ww w.reuters.com/article/us-bulgaria-energy-russia/bulgar ia-open-to-russian-role-in-nuclear-power-project-idUSK CN1IM1LT

Bardi, L., Rhodes, M., \& Nello, S. S. (2002). Enlarging the European Union: challenges to and from Central and Eastern Europe: introduction. International Political Science Review, 23(3), 227-233. doi:10.1177/0192512102023003001

Batsaikhan, U., Darvas, Z., \& Raposo, I. G. (2018). People on the move: migration and mobility in the European Union. Brussels: Bruegel.

BBC. (2006). Syarat Eropa bagi calon anggota. Retrieved from http://www.bbc.co.uk/indonesian/news/sto ry/2006/05/060516_euverdict.shtml

Bilefsky, D. (2007, January 2). Romania and Bulgaria celebrate entry into European Union. The New York Times. Retrieved from https://www.ny times.com/2007/01/02/world/europe/02union.html

Brown, J. (1986). The Challenge to Soviet Interests in Eastern Europe: Bulgaria and Czechoslovakia. Santa Monica, CA: RAND Corporation.

Chandler, M. (2017, November 16). Bulgaria and Romania sill have not met conditions of joining EU 10 years after accession. Express UK. Retrieved from https://www.express. co.uk/news/world/880222/Romania-Bulgaria-EU-Brus sels-Cooperation-and-Verification-Me

Commission Of The European Communities. (2006). Monitoring report on the state of preparedness for EU membership of Bulgaria and Romania. Retrieved from https://ec.europa.eu /neighbourhoodenlargement/sites/near/files/pdf/key_docu ments/2006/sept/report bg $r$

Commission Of The European Communities. (2007). Report From The Commission To The European Parliament And The Council: on Bulgaria's progress on accompanying measures following accession. Retrieved from https://eurlex.eu ropa.eu/legalcontent/EN/TXT/PDF/?ur

Commission, E. (2018). Accession criteria. Retrieved from https://ec.europa.eu/neighbourhood-enlargement/poli cy/glossary/terms/accession-criteria_en

Communities, C. O. (2018). Report from the commission to the european parliament and the council: on bulgaria's progress on accompanying measures following accession. Retrieved from https://ec.europa.eu/info/sites/info/files/progress-

Cuaresma, J. C., Fidrmuc, J., \& Silgoner, M. A. (2005). On the road: the path of Bulgaria, Croatia and Romania to the EU and the Euro. Europe Asia Studies, 57(6), 843-858. doi:doi.org/10.1080/108009668130500199418

Dimitrova, A., \& Buzogany, A. (2014). A post accession policy making in Bulgaria and Romania: can non-state actors use 
EU rules to promote better governance? Journal of Common Market Studies, 52(2), 139-156.

doi:doi.org/10.1111/jcms.12084

European Commission. (2014). End of restrictions on free movement of workers from Bulgaria and Romania. Retrieved from http://europa.eu/rapid/press-release MEMO-14-1_en.html

European Commission. (2015). Standard eurobarometer: public opinion in the European Union. Brussels: European Union.

European Migration Network. (2014). End of restrictions on free movement of workers from Bulgaria and Romania. Retrieved from https://emnbelgium.be/news/end-restrictions tions-free-movement-workersbulgaria-and-roma nia-free-movement-workersbulgaria-and-romania

Evans, G., \& Mellon, J. (2015, December 18). The immigration and euroscepticism: the rising stor. The Guardian. Retrieved from https://www.theguardian.com/news/datablog/2015/ dec/18/immigrationeuroscepticism-rising-storm-eu-referen dum

Favell, A. (2008). The new face of east - West migration. Journal of Ethnic and Migration Studies, 34(5), 701-716. doi:10.1080/13691830802105947

Fawcett, L., \& Hurrel, A. (1995). Regionalism In World Politics. Oxford: Oxford University Press.

Fiorentino, M. (2018, June 8). Russian designed nuclear power plant causes tension in Bulgaria. Euronews. Retrieved from https://www.euronews.com/2018/06/08/russian-de signed-nuclear-power-plant-causes-tension-in-Bulgaria

Grabbe, H. (2002). European Union conditionality and the acquis communautaire. International Political Science Review, 23(3), 249-628. doi:10.1177/0192512102023003003

Haas, E. (2004). The Uniting Of Europe. Notre Dame: University of Notre Dame Press.

Harmsen, R., \& Spiering, M. (2004). Euroscepticism: party politics, national identity and party politics and European integration. Amsterdam: Rodopi BV.

Hjerm, M. (2003). National sentiments in eastern and Western Europe. Nationalities Papers, 31(4), 413-429. doi:10.1080/0090599032000152933

Horvat, S., \& Štiks, I. (2013, July 1). Croatia has become the latest member of the EU periphery. The Guardian. Retrieved from https://www.theguardian.com/commentisfree/2013/ jul/01/croatia-latest-member-eu-periphery

Ilonszki, G. (2009). National discontent and EU support in central and Eastern Europe. Europe Asia Studies, 61 (6), 1041-1057. doi:10.1080/09668130903063591

Jeffery, S. (2005, June 2). Q\&A: The European constitution. The Guardian. Retrieved from https://www.theguardi an.com/world/2005/jun/02/eu. france2

Malova, D., \& Dolny, B. (2008). The Eastern enlargement of The European Union: challlenges to democracy? Human Affairs, 8, 67-80. doi:10.2478/v10023-008-0006-4

Miroslav, N., \& Damnjanovic, J. (2014). EU Eastern enlargement: economic effects on new members 2000-2012. Journal of Economic Integration, 29(2), 210-243. doi:10.11130/ jei.2014.29.2.210

Nello, S. (2007). Preparing for enlargement in the European Union: the tensions between economic and political integration. International Political Science Review, 23(3), 291-317. doi:10.1177/0192512102023003005

Noutcheva, G., \& Bechev, D. (2008). The successful laggards: Bulgaria and Romania's accession to the EU. Societies, 21(1), 114-140. doi:10.1177/0888325407311793

Pop, V. (2013, March 4). Germany to veto Schengen enlargement. Euobserver. Retrieved from https://euobserver.com/jus tice/119261

Raitio, J., \& Raulus, H. (2017). The UK EU referendum and the move towards Brexit. Maastricht Journal of European and Comparative Law, 25(1), 25-42. doi:10.1177/1023263X17699336

Rezler, P. (2011). The Copenhagen criteria: are they helping or hurting the European Union? Touro International Law .Review, 12(2), 390-411.

Schimmelfennig, F. (2000). International socialization in the new Europe: rational action in an institutional environment. European Journal of International Relations, 6(1), 109-139. doi:10.1177/1354066100006001005

Schimmelfennig, F. (2003). Strategic action in a community environment: the decision to enlarge the European Union to the East. Comparative Political Studies, 36(1-2), 156-183. doi:10.1177/0010414002239375

Schimmelfennig, F., \& Sedelmeier, U. (2002). Theorizing EU enlargement: research focus, hypotheses, and the state of research. Journal of European public policy, 9(4), 500-528. doi:10.1080/13501760210152411

Schneider, C. (2009). Conflict, negotiation and European Union enlargement. Cambridge: Cambridge University Press.

Scully, R., \& Jones, R. (2010). Europe, Regions and European Regionalism. New York: Palgrave Macmillan.

Taseva, E. (2012). The new European commission anti-corruption package: towards a more efficient fight againts corruption? New Journal of European Criminal Law, 3(4), 344-362. doi:10.1177/203228441200300308

Tchalakov, I., \& Hristov, I. (2018). Bulgaria Short Country Report. Sofia: Euratom Research.

Tenzer, N. (2018, January 26). What to expect from Bulgaria's EU presidency? . Euobserver. Retrieved from https://euobserv er.com/opinion/140697

The Economist. (2014). Russia's cancellation of a big pipeline has taught its friends a lesson. Retrieved from https://ww w.economist.com/europe/2014/12/04/pipe-down

The Guardian. Croatia has become the latest member of the EU periphery. (2018). Retrieved from https://www. theguardian com/commentisfree/2013/jul/01/croatia-latest-member -eu-periphery

Todorov, A. (2007). The evolution of the post-communist bulgarian party syste. Sofia: New Bulgarian University Press.

Uysal, B. T. (2013). Bulgaria and European Union: minorities situation in Bulgaria during the integration process for the European Union. Karadeniz Arastirmalari, 36, 1-22.

Vetličič, M. S., \& Trtnik, A. (1999). European Union enlargement: is enthusiasm waning? Eastern European Economics, 37(4), 70-96. doi:10.1080/00128775.1999.11648696

Wincott, D. (2017). Brexit dilemmas: new opportunities and tough choices in unsettled times. The British Journal of Politics and International Relations, 9(4), 680-695. doi:10.1177/1369148117725316

Workpermit. (2007). Bulgaria and Romania join the European 
182 JURNAL HUBUNGAN INTERNASIONAL

VoL. 8, NO. 2 (2019): October 2019-March 2020

Union. Retrieved from http://workpermit.com/news/Bulgar ia-and-romania-join-european-union20070105

Yesilada, B., Efird, R., \& Noordijk, P. (2006). Competition among giants: a look at how future enlargement of the European union could affect global power transition. International Studies Review, 8, 607-622. doi:10.1111/

j.1468-2486.2006.00629.x 